\title{
Growth and Survival of Perennial Tropical Grasses in North Georgia
}

\author{
E. R. BEATY, ALBERT E. SMITH, AND EDWARD E. \\ WORLEY
}

Highlight: Coastal, midland, and common bermudagrasses and Pensacola and Wilmington bahiagrasses were established and grown in the Limestone Valley and upland province of Georgia at six rates of nitrogen ( $N$ ) fertilization. Forage and weed yields reflected $N$ fertilization rates. Bermudagrasses outyielded bahiagrasses at high $N$ levels, and weed production composed a significant part of the total harvested. Common and midland bermudagrass and Wilmington bahiagrass are significantly more winter hardy than are coastal bermuda or Pensacola bahia.

Grasses of tropical and subtropical origin, because of their aggressive growth habits, tolerance to diverse management practices, and production reliability, are becoming more important for grazing in the temperate Southeast. Survival of common, coastal, and midland bermudagrass (Cynodon dactylon (L.) Pers.) and Pensacola and Wilmington bahiagrass (Paspalum notatum var. saurae Perodi.) are limited in the North and East by winter cold and West by dry weather.

The purpose of this investigation was to compare the perennial summer grasses as to forage production, winter survival, and weed production under conditions where stand retention and survival become difficult and to establish the influence of nitrogen $(\mathrm{N})$ on the forage production and survival of these forage grasses.

\section{Literature Review}

Certain varieties of bermudagrass and bahiagrass will grow from central Texas to Kentucky. However, no one variety is superior over the entire area. Coastal bermudagrass is considered superior for hay and grazing over much of the Coastal Plain (Burton, 1954), while Pensacola bahiagrass has been found to do well on deep sands and nonfertile soils of the same area. (Tan et al., 1970). The northern limits for these species cannot be well defined, as severity of winter cold varies significantly. Central Georgia to Jackson, Miss., has been considered the northern limit of Pensacola bahiagrass. Coastal bermudagrass survives on well-drained soils as far north as the

The authors are professor of agronomy, University of Georgia, Athens; assistant professor of agronomy, Georgia Experiment Station; and superintendent, Northwest Georgia Branch Experiment Station, Calhoun.

Manuscript received March 20, 1972.
Tennessee line. However, it will winter-kill south of that during excessively cold winters and when grown on shallow and wet soils. Trial plantings of midland bermudagrass and Wilmington bahiagrass by the Soil Conservation Service have survived in Oklahoma, northern Arkansas, and Kentucky; and common bermudagrass will survive in the Great Lakes Region (Burton, Personal Communication). Reported research on stand damage to perennial grasses by cold temperatures in the Southcast has been limited to specific conditions (Adams and Twerski, 1960).

The relationship between forage yield and height of clip has been pointed out by Ethredge and Beaty (1969). In that work, forage yields were reduced by $25 \%$ when clipping height of coastal bermudagrass was increased from 0 to 2.8 inches. Up to 2,200 pounds of dry forage was harvested by clipping at 0 inches, while less than 50 pounds would be harvested by clipping at 2.8 inches.

The significance of clipping height is greater with shortgrowing grasses such as common bermudagrass and bahiagrass than with the taller growing coastal and midland bermudas, (Beaty et al., 1968), since up to $60 \%$ of total vegetation may be below 2 inches.

Recently, it has been shown that atmospheric $\mathrm{N}$ can be fixed by some bahiagrasses (Kass et al., 1971), while Tan and Beaty (1971) have shown that bahiagrass can concentrate fertilizer elements in the soil surface.

Seasonal forage production patterns of coastal bermuda and Pensacola bahia have been established (Beaty et al., 1960 and 1961) and effects of fertilizer on forage production have also been established, (Beaty et al., 1960; and Adams and Stelly, 1958). Weed control in pastures is frequently discussed in the literature, but weed production and their possible utilization in perennial forage crops has not been researched.

\section{Procedure}

The investigation was conducted at Calhoun, Ga., in the Limestone Valley and upland soil province. The Montivallo silt loam soil, a widely occurring entisol, had a shallow $A$ horizon and was poorly drained. The subsoil was composed of incompletely decomposed shale. At the beginning of the investigtion, the surface soil had a $\mathrm{pH}$ value of 6.1 .

On June 10,1963, whole plots of common, coastal, and midland bermudagrass were sprigged on $1-\mathrm{ft}$ centers, and 
Pensacola and Wilmington bahiagrass were seeded at 30 lb/acre. No fertilizer was applied at planting. During the springs of 1964 and $1965,30 \mathrm{lb} /$ acre $\mathrm{N}$ were applied to all plots. During the spring of 1966 and annually during 1967, 1968 , and $1969, \mathrm{~N}$ treatments of $0,50,100,200,400$, and $600 \mathrm{lb} /$ acre were made on 6 -ft by 10 -ft split plots. Treatments were replicated four times. Nitrogen treatments were split into four equal applications: $1 / 4$ in late April and 1/4 after the first, second, and third clippings. Applications of $\mathrm{P}_{2} \mathrm{O}_{5}$ and $\mathrm{K}_{2} \mathrm{O}$ were made as indicated by soil tests.

Plots were clipped when seed heads were observed on the $200 \mathrm{lb} /$ acre $\mathrm{N}$-treated coastal bermudagrass plots. Clipping dates were usually June 5 to 10 , July 10 to 20 , August 20 to 30 , and October 20 to 25 . For forage and weed yields, $25 \mathrm{ft}^{2}$ of each plot was clipped and dried at $165^{\circ} \mathrm{F}$ for dry weight measurements. Plot clipping was completed with a sickle bar mower set to clip to a 2.5 inch stubble height. Weed production was established by clipping on April 18, in 1967, 1968, 1969, and May 5 in 1970; all species except the crop planted were considered weeds.

On February 5, 1970, forage crop survival was established by enclosing 6-inch sod cores in plastic in the greenhouse and counting developed tillers on February 27, 1970. Stand survival in the field was quantified by visual estimates and counting live tillers on May 5 and August 4, 1970.

\section{Results and Discussion}

\section{Crop Establishment}

All grasses were slow to establish. By late 1964, the bermudagrass plots were well established. However, bahiagrass plots were not completely established by the first clipping in 1966, 3 years after seeding. Soils of the Limestone Valley are heavier than Coastal Plain soils, and the heavier soil combined with cooler temperatures likely influenced establishment of the subtropical grasses. The slow establishment corroborates the findings of Richardson and Diseker (1965).

\section{Forage Yields}

Average yields for the different harvested grasses (Fig. 1) indicate that coastal bermudagrass would be most desired as forage grass, with midland and common bermudagrass being second and third. The two bahiagrasses produced 1,500 to $2,000 \mathrm{lb}$ lower yields as compared to coastal bermudagrass.

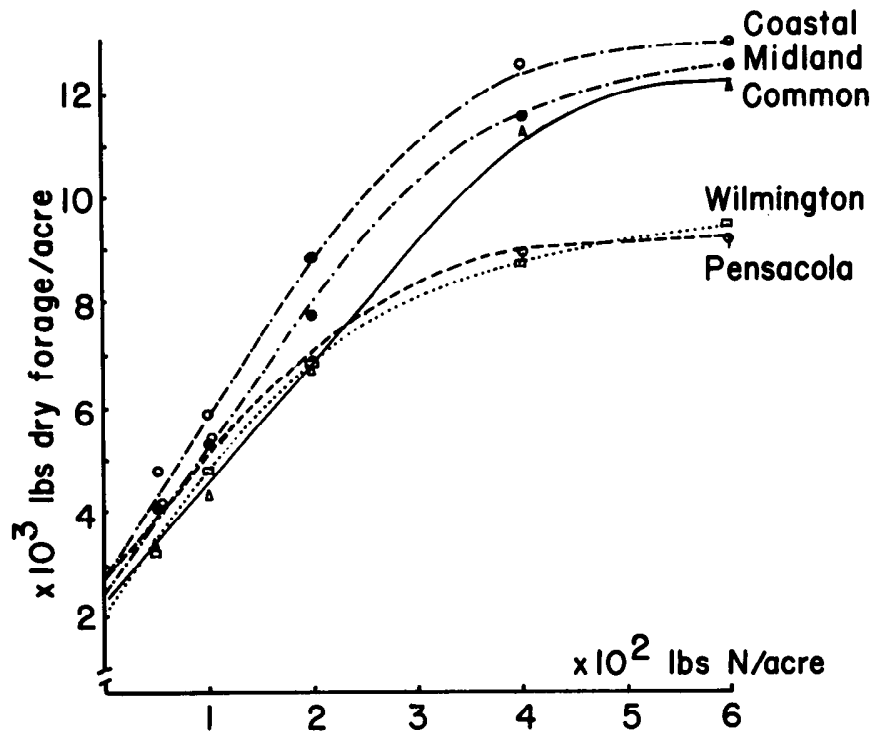

Fig. 1. Yield of three bermudagrasses and two bahiagrasses by $N$ rates at Calhoun, Georgia, 1966-1969.
Coastal bermudagrass, where adapted because of its upright growth habit, would be preferred for hay production. However, the lower-growing common and midland bermudagrass would probably produce as much forage for grazing purposes as coastal bermudagrass. Over most of the Southeast, grazing is the predominate use of bermudagrass.

Approximately $60 \%$ of the forage produced by the lowgrowing bahiagrasses was below the 2.5-inch mowing height used in this investigation (Beaty et al., 1968). When yield data of bahiagrass reported in Figure 1 are evaluated using that evidence, all five grasses would be considered essentially equal in yield for grazing purposes, and coastal and midland bermudagrass would be superior for haying. The $\mathrm{N}$-fixing capacities of bahiagrass have not been delineated, but related research suggest significant quantities may be. Stand maintenance is no problem with bahiagrasses in areas where winterkilling does not occur.

\section{Crop Competition with Weeds}

Plants harvested in this study and classed as weeds included Carolina crainsbill (Geranium carolinianum L.), common vetch (Vicia sativa L.), ryegrass (Lolium multiflorium Lam.), little barley (Hordium pusillum Nutt), hop clover (Trifolium procumbens L.), white clover (T. repens L.), wild onion (Allium vineale L.), and Kentucky bluegrass (Poa pratensis L.). During early spring, before May 1, when the bermudagrasses and bahiagrasses compose only a small fraction of available forage, these species are highly nutritious and are readily grazed by livestock. However, they are not the species seeded and were classed as weeds in this study. During the summer growing season, all five seeded grasses produced weed free stands.

Weed production, as a complement to forage production of bermuda and bahiagrasses, was influenced significantly by both crop and $\mathrm{N}$ rate (Table 1 ). Lowest weed production was on coastal bermudagrass plots; highest weed production was on Pensacola bahiagrass plots. These data indicate that under environmental conditions of the Limestone Valley soil province, coastal bermudagrass competes more vigorously with weeds than other grasses investigated. Coastal would appear to offer greatest competition to interseeded crops.

It is possible that certain of the weedy species furnish

Table 1. Average annual weed production (lb/acre, dry wt) on five subtropical grasses treated with various rates of nitrogen fertilizer, Calhoun, Georgia 1967-1970.

\begin{tabular}{|c|c|c|c|c|c|}
\hline \multirow[b]{2}{*}{$\mathrm{N}$ rate } & \multicolumn{3}{|c|}{ Bermudagrass } & \multicolumn{2}{|c|}{ Bahiagrass } \\
\hline & Common & Coastal & Midland & Pensacola & Wilmington \\
\hline 0 & $451_{\mathrm{c}}^{\mathrm{def}}$ & $312_{c}^{f}$ & $560 \begin{array}{l}\text { def } \\
\text { bc }\end{array}$ & $323_{\mathrm{c}}^{\mathrm{f}}$ & $388_{\mathrm{c}}^{\text {ef }}$ \\
\hline 50 & $526 \underset{b c}{\mathrm{def}}$ & $496 \underset{b c}{\text { def }}$ & $71 \underbrace{\mathrm{def}}_{\mathrm{abc}}$ & $405_{\mathrm{c}}^{\mathrm{ef}}$ & 479 bc \\
\hline 100 & $601 \mathrm{def}$ & $419_{\mathrm{c}}^{\mathrm{def}}$ & $636_{\mathrm{bc}}^{\mathrm{def}}$ & $628 \frac{\mathrm{def}}{\mathrm{abc}}$ & $577 \begin{array}{ll}\text { def } \\
\text { bc }\end{array}$ \\
\hline 200 & $790 \begin{array}{l}\text { def } \\
\text { abc }\end{array}$ & $628 \frac{\mathrm{def}}{\mathrm{bc}}$ & $768 \begin{array}{l}\text { def } \\
\text { abc }\end{array}$ & $655 \frac{\text { def }}{b c}$ & $739 \begin{array}{l}\text { def } \\
\text { abc }\end{array}$ \\
\hline 400 & $914 \begin{array}{l}\text { def } \\
\text { abc }\end{array}$ & $826_{\mathrm{abc}}^{\mathrm{def}}$ & $1014 \begin{array}{l}\text { bdef } \\
\text { abc }\end{array}$ & $1700_{\mathrm{ab}}^{\mathrm{abc}}$ & $1138_{\text {abc }}^{\text {bcde }}$ \\
\hline 600 & $920 \begin{array}{l}\text { def } \\
\text { abc }\end{array}$ & $661 \mathrm{def}$ & $1200 \begin{array}{l}\mathrm{bcd} \\
\mathrm{abc}\end{array}$ & $1926_{\mathrm{a}}^{\mathrm{a}}$ & $1699_{\mathrm{ab}}^{\mathrm{ab}}$ \\
\hline Avg & 700 & 557 & 815 & 940 & 837 \\
\hline
\end{tabular}

${ }^{1}$ Means within a $\mathrm{N}$ rate followed by the same subscript letter, and means within a column followed by the same superscript letter, are not significantly different at the 0.05 level of probability. 
Table 2. Survival (\%) of five subtropical grasses treated with various rates of nitrogen fertilizer, Calhoun, Georgia, 1970.

\begin{tabular}{|c|c|c|c|c|c|}
\hline \multirow[b]{2}{*}{ N rate } & \multicolumn{3}{|c|}{ Bermudagrass } & \multicolumn{2}{|c|}{ Bahiagrass } \\
\hline & Common & Coastal & Midland & Pensacola & Wilmington \\
\hline 0 & $100^{a}$ & $96_{a}^{a b}$ & $92_{\mathrm{a}}^{\mathrm{ab}}$ & $35_{\mathrm{d}}^{\mathrm{e}}$ & $100_{a}^{a}$ \\
\hline 50 & $98_{\mathrm{a}}^{\mathrm{ab}}$ & $100_{\mathrm{a}}^{\mathrm{a}}$ & $100_{a}^{a}$ & $16_{\mathrm{e}}^{\mathrm{ef}}$ & $100_{a}^{a}$ \\
\hline 100 & $93 \underset{a}{a b}$ & $100_{a}^{a}$ & $98_{\mathrm{a}}^{\mathrm{ab}}$ & $16 \mathrm{e}_{\mathrm{e}}^{\mathrm{ef}}$ & $100_{\frac{a}{a}}^{a}$ \\
\hline 200 & $98_{\mathrm{a}}^{\mathrm{ab}}$ & $92 \underset{\mathrm{a}}{\mathrm{a}}$ & $100_{\mathrm{a}}^{\mathrm{a}}$ & $11_{\mathrm{e}}^{\mathrm{f}}$ & $100_{a}^{a}$ \\
\hline 400 & $93_{a}^{a b}$ & $75_{\mathrm{bc}}^{\mathrm{bcd}}$ & $98_{a}^{a b}$ & $3 \frac{f}{e}$ & $95_{\mathrm{a}}^{\mathrm{ab}}$ \\
\hline 600 & $94_{a}^{\mathrm{ab}}$ & $64_{c}^{\mathrm{cd}}$ & $85_{a b}^{a b}$ & $6_{e}^{f}$ & $63_{\mathrm{c}}^{\mathrm{cd}}$ \\
\hline Avg & 96 & 88 & 96 & 15 & 93 \\
\hline
\end{tabular}

${ }^{1}$ Means within a $\mathrm{N}$ rate followed by the same subscript letter, and means within a column followed by the same superscript letter, are not significantly different at the $\mathbf{0 . 0 5}$ level of probability.

quality forage during early portions of the grazing season. Growth of grazcablc wceds in a pasture when the seeded species are not growing would appear to be desirable in a pasture management program where competition with the crop species is not detrimental to forage production.

\section{Winter Survival}

During 3 of the 4 experimental years, winter survival of all species was satisfactory. However, during the winter of 1969-1970, mean temperatures were below normal, and cold injury to stands was noted in two species (Table 2). Common bermudagrass used in this test was of a local ecotype, and excellent survival was obtained.

Survival of coastal bermudagrass on plots treated with up to $100 \mathrm{lb} /$ acre $\mathrm{N}$ was good. However, stand damage increased as $\mathrm{N}$ rates were increased above $100 \mathrm{lb} / \mathrm{acre}$. Stand reductions of 8,25 , and $36 \%$ on plots receiving 200,400 , and $600 \mathrm{lb} /$ acre $\mathrm{N}$ would indicate Calhoun, $\mathrm{Ga}$., is close to the northern limit of dependability for coastal bermudagrass. By August 4, 1970, coastal plots had reestablished stands, but much of the season had been lost to forage production. Midland bermudagrass survived well at this location, except at the $600 \mathrm{lb} /$ acre $\mathrm{N}$ treatments.

Stands of Pensacola bahiagrass were damaged at all $\mathrm{N}$ levels and had not reestablished by August 4, 1970, indicating Calhoun, Ga., to be north of the area of adaptation of this grass. Stands of Wilmington bahiagrass were excellent up to $400 \mathrm{lb} /$ acre $\mathrm{N}$. Only at $600 \mathrm{lb} /$ acre were stands noticeably reduced. Bahiagrass is only recommended for grazing, and the $\mathrm{N}$ application should not exceed $150 \mathrm{lb} / \mathrm{acre}$ (Beaty et al., 1969).

The data obtained in this investigation show that winter stand damage to coastal bermudagrass and Pensacola bahiagrass may be severe. During some years, winter damage to stands may cause forage shortages the following year. By selecting midland bermudagrass or Wilmington bahiagrass, loss in forage production due to winter injury will be minimal. Common bermudagrass is more disease susceptible than midland and therefore inferior. Survival and forage yields of midland bermudagrass and Wilmington bahiagrass appear to make them best suited for forage grasses in this area of Georgia.

\section{Literature Cited}

Adams, W. E., and Matthias Stelly. 1958. Fertility requirements of Coastal bermuda (Cynodon dactylon [L.] Pers.) when grown in association with crimson clover in the Piedmont region: I. Yield response to fertilization. Agron. J. 50:457-459.

Adams, W. E., and Marvin Twersky. 1960. Effect of soil fertility on winter killing of Coastal bermudagrass. Agron. J. 52:325-326.

Beaty, E. R., R. A. McCreery, and John D. Powell. 1960. Response of Pensacola bahiagrass to nitrogen. Agron. J. 52:453-455.

Beaty, E. R., D. D. Hayes, and R. A. McCreery. 1961. A comparison of coastal and common bermudagrass on a shallow drouthy soil. I. Range Manage. 14:92-95.

Beaty, E. R., R. L. Stanley, and John D. Powell. 1968. Effect of height of cut on yield of Pensacola bahiagrass. Agron. J. 60:356-359.

Beaty, E. R., John D. Powell, and James H. Edwards. 1969. Forage and animal gains of coastal bermudagrass and Pensacola bahiagrass. J. Range Manage. 22:318-321.

Burton, Glenn W. 1954. Coastal Bermudagrass. Georgia Coastal Plain Exp. Sta. Bull. N. S. 2.

Ethredge, W. G., and E. R. Beaty. 1969. Coastal bermudagrass yields and season of growth as influenced by $\mathrm{N}$ rate, height and frequency of clip. Proc. Assoc. South. Agr. Workers 66:80.

Kass, Donald L., Matthew Drosdoff, and Martin Alexander. 1971. Nitrogen fixation by Azotobacter paspali in association with bahia (Paspaluin notatum). Soil Sci. Soc. Amer. Proc. 35:286-289.

Richardson, E. E., and Ellis G. Diseker. 1965. Establishing and maintaining roadside cover in the Piedmont Plateau of Georgia. Agron. J. 57:561-564.

Tan, K. H., and E. R. Beaty. 1971. Organic matter, N, and base accumulation under Pensacola bahiagrass. J. Range Manage. $25: 38-40$.

Tan, K. H., J. H. Edwards, E. R. Beaty, and R. A. McCreery. 1970. Soil organic matter content and composition as related to ley clipping management and fertilization. Soil Sci. Soc. Amer. Proc. $34: 610-612$.

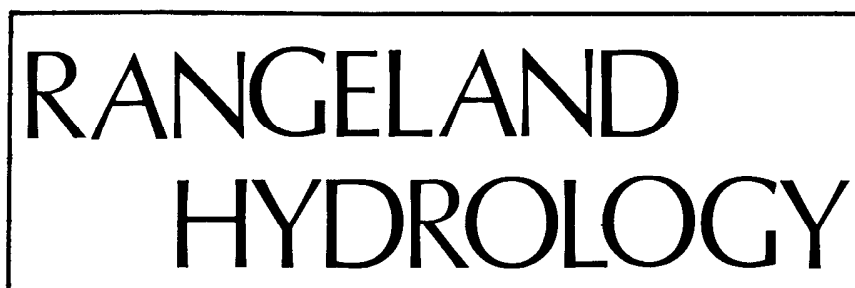

Farrel A. Branson, Geological Survey, USDI

Gerald F. Gifford, Utah State University J. Robert Owen, Geological Survey, USDI

Here is a publication, the first in the Society's RANGE SCIENCE SERIES, that presents a brief but comprehensive summary review of the principles and problems of watershed management on rangelands.

Rangeland Hydrology is an ideal aid for classroom instruction, ${ }^{*}$ as well as an excellent reference for ranchers, research scientists, field workers, and administrators-especially so if one is not quite up-to-date in this particular aspect of range management.

With 72 pages of illustrated text and 234 selected references, this booklet succinctly tells about the relationships between rangeland vegetation and precipitation, interception, runoff, infiltration, erosion and sedimentation, geomorphology, and evaporation/transpiration.

viii +84 p. Illus. $\$ 1.75$ per copy, postpaid.

Order from Society for Range Management, 2120 South Birch Street, Denver, Colorado 80222.

* Special bulk order prices available to college or university depart ments or bookstores. Write to above address for information. 